DOI 10.5012/bkcs.2011.32.3.894

\title{
A Two-Dimensional Terrace-Like $N$-heterocyclic-Pb(II) Coordination Compound: Structure and Photoluminescence Property
}

\author{
Kui-Rong Ma," Yu-Lan Zhu, Yu Zhang, Rong-Qing Li, and Li Cao \\ Jiangsu Key Laboratory for Chemistry of Low-dimensional Materials, School of Chemistry and Chemical Engineering, \\ Huaiyin Normal University, Huaian 223300, P.R. China. ${ }^{*}$ E-mail: kuirongma@163.com \\ Received December 6, 2010, Accepted January 7, 2011
}

\begin{abstract}
The first example of lead compound from $\mathrm{Pb}\left(\mathrm{NO}_{3}\right)_{2}$ and $\mathrm{H}_{3} \mathrm{~L} N$-heterocyclic ligand $\left(\mathrm{H}_{3} \mathrm{~L}=\left(\mathrm{HO}_{2} \mathrm{C}\right)_{2}\left(\mathrm{C}_{3} \mathrm{~N}_{2}\right)\right.$ $\left.\left(\mathrm{C}_{3} \mathrm{H}_{7}\right) \mathrm{CH}_{2}\left(\mathrm{C}_{6} \mathrm{H}_{4}\right)\left(\mathrm{C}_{6} \mathrm{H}_{3}\right) \mathrm{CO}_{2} \mathrm{H}\right),\left[\mathrm{Pb}_{4}\left(\mathrm{~L}^{\prime}\right)_{4}\right] \cdot 5 \mathrm{H}_{2} \mathrm{O} 1\left(\mathrm{~L}^{\prime}=\mathrm{OOC}\left(\mathrm{C}_{3} \mathrm{H}_{7}\right)\left(\mathrm{C}_{3} \mathrm{~N}_{2}\right) \mathrm{CH}_{2}\left(\mathrm{C}_{6} \mathrm{H}_{4}\right)\left(\mathrm{C}_{6} \mathrm{H}_{3}\right) \mathrm{COO}\right)$, has been obtained under hydrothermal condition by decarboxylation, and characterized by elemental analysis, IR, TGDTA, and single-crystal X-ray diffraction. Compound 1 possesses a rare two-dimensional upper-lower offset terrace-like layer structure. In $\mathbf{1}$, crystallographic distinct $\mathrm{Pb}$ (II) ion adopts five-coordination geometry, and two lattice water molecules occupy the voids between 2-D layers. Results of solid state fluorescence measurement indicate that the emission band $458 \mathrm{~nm}$ may be assigned to $\pi^{*}-n$ and $\pi^{*}-\pi$ electronic transitions within the aromatic systems of the ligand L', however, the emission bands centred at $555 \mathrm{~nm}, 600 \mathrm{~nm}$ and $719 \mathrm{~nm}$ may be derived from phosphorescent emission $\left(\lambda_{\text {excitation }}=390 \mathrm{~nm}\right)$.
\end{abstract}

Key Words : $N$-heterocyclic, Lead compound, Crystal structure, Photoluminescence

\section{Introduction}

Because of toxicity of lead, the study of lead compounds and removal of lead by chelating agents through coordination in biological system always attracts investigator's attention. ${ }^{1}$ Lead(II) ion possesses a large radius, a variable stereochemical activity and a flexible coordination environment, which can provide unique opportunities for the construction of novel metal-organic frameworks (MOFs) ${ }^{2,3}$ The construction of $\mathrm{Pb}(\mathrm{II})-\mathrm{MOF}$ with fascinating architectures is a rapidly developing area of research in recent years. $^{4-10}$ 1-[(2-Carboxybiphenyl-4-yl)methyl]-2-propylimidazole-4,5-dicarboxylic acid $\left(\mathrm{H}_{3} \mathrm{~L}\right)$, as a type of $N$-heterocyclic ligand (O- or N-donor), can be protonated or deprotonated to produce an infinite variety of MOF structures. When the ligand $\mathrm{H}_{3} \mathrm{~L}$ is conducted at $150{ }^{\circ} \mathrm{C}$ in the presence of organic amine and $\mathrm{H}_{2} \mathrm{O}$, regioselectivity of decarboxylation can happen. ${ }^{11}$ Then a new ligand, 1-[(2-carboxybiphenyl-4-yl)methyl]-2-propylimidazole-4-carboxylic acid $\left(\mathrm{H}_{2} \mathrm{~L}^{\prime}\right)$, is obtained (Scheme 1). The architecture of $\mathrm{Pb}(\mathrm{II})-$ MOF constructed from the ligand $\mathrm{H}_{3} \mathrm{~L}$ has never reported to date. Accordingly, we firstly reported the synthesis and crystal structure of a new 2-D lead-MOF $\left[\mathrm{Pb}_{4}\left(\mathrm{~L}^{\prime}\right)_{4}\right] \cdot 5 \mathrm{H}_{2} \mathrm{O} 1$. Moreover, the heat-treated products at various temperatures were analyzed by the solid-state photoluminescence.

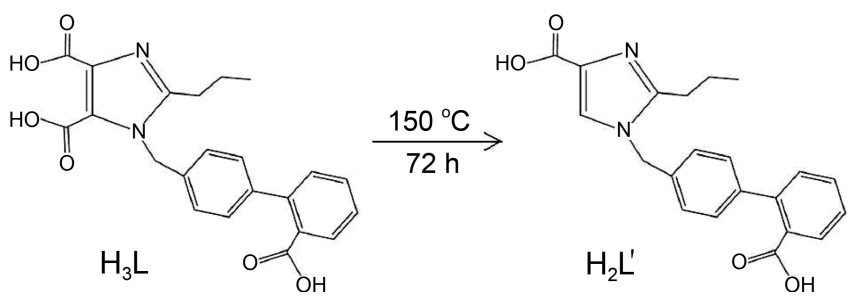

Scheme 1. Decarboxylation of ligand $\mathrm{H}_{3} \mathrm{~L}$.

\section{Experimental Section}

Materials and General Methods. All chemical reagents were obtained from commercial sources and used without further purification. The elemental analysis was conducted on a Perkin-Elmer 2400 LC II elemental analyzer. IR spectrum was carried out on an AVATAR-360 FT-IR spectrometer with $\mathrm{KBr}$ pellets in the $400 \mathrm{~cm}^{-1}-4000 \mathrm{~cm}^{-1}$ region. Thermo-gravimetric (TG) and differential thermal analysis (DTA) were performed on a TG/SDTA851e analyzer by METTLER-TOLEDO Co. of Switzerland in an atmospheric environment at a heating rate of $10{ }^{\circ} \mathrm{C} \cdot \mathrm{min}^{-1}$. Emission and excitation spectra were recorded on a PerkinElmer LS 55 fluorescence spectrometer. The powder $\mathrm{x}$-ray diffraction (XRD) patterns was collected on a Thermo ARL X'TRA diffractometer using graphite-monochromated $\mathrm{Cu} \mathrm{K} \alpha$ radiation $(\lambda=1.5418 \AA)$ in the angular range $2 \theta=4^{\circ}-40^{\circ}$ with stepping size of $0.02^{\circ}$ and counting time of $4 \mathrm{~s}$ per step.

Synthesis of $\left[\mathrm{Pb}_{\mathbf{4}}\left(\mathbf{L}^{\prime}\right)_{4}\right] \cdot \mathbf{5} \mathbf{H}_{2} \mathbf{O} \mathbf{1}$. A mixture of $0.265 \mathrm{~g}(0.8$ mmol) $\mathrm{Pb}\left(\mathrm{NO}_{3}\right)_{2} \cdot 6 \mathrm{H}_{2} \mathrm{O}, 0.183 \mathrm{~g}(0.4 \mathrm{mmol}) \mathrm{H}_{3} \mathrm{~L}$ and 10.0 $\mathrm{mL}(555 \mathrm{mmol})$ deionized water was sealed in a $15 \mathrm{~mL}$ Teflon-lined stainless steel autoclave. The initial $\mathrm{pH}$ value of solution was adjusted to 10.2 , and then it was heated in molar ratio $0.8: 0.4: 555$ at $150{ }^{\circ} \mathrm{C}$ for $72 \mathrm{~h}$. The final $\mathrm{pH}$ value was 9.5. The crystalline of $\mathbf{1}$ (colorless block-shaped) was collected by vacuum filtration, washed thoroughly with deionized water and dried in air (yield $59 \%$ based on Lead). Elemental analysis (\%), $\mathrm{C}_{84} \mathrm{H}_{82} \mathrm{~N}_{8} \mathrm{O}_{21} \mathrm{~Pb}_{4}$ : C, 42.62; $\mathrm{H}, 3.55$; $\mathrm{N}, 4.79$. Calcd.: C, $42.56 ; \mathrm{H}, 3.46 ; \mathrm{N}, 4.73$. IR data $\left(\mathrm{cm}^{-1}\right)$ 3606 (w), 3392 (s), 3226 (w), 2962 (m), 2929 (w), 2869 (w), $1625(\mathrm{w}), 1584(\mathrm{~s}), 1510(\mathrm{w}), 1444(\mathrm{w}), 1376(\mathrm{~s}), 1332(\mathrm{~m})$, $1253(\mathrm{~s}), 1143(\mathrm{~m}), 1081(\mathrm{~m}), 1004(\mathrm{~m}), 862(\mathrm{w}), 833(\mathrm{~m})$, $752(\mathrm{~m}), 665(\mathrm{w}), 572(\mathrm{w}), 528(\mathrm{w}), 482(\mathrm{w})$ (see supplement figure $\mathrm{S} 1)$. 
X-ray Crystallography. Intensity data were collected on a Bruker SMART APEX II diffractometer equipped with a graphite-monochromated Mo K $\alpha$ radiation $(\lambda=0.71073 \AA)$ at $293 \mathrm{~K}$ using the $\omega-2 \theta$ scan technique. The structure was solved by direct methods and refined by full-matrix leastsquares fitting on $F^{2}$ by SHELXL-97. A total of 14922 reflections were collected, of which $4020\left(R_{\text {int }}=0.0468\right)$ were unique. All non-hydrogen atoms were located from the initial solution and refined with anisotropic thermal parameters. The position of hydrogen atoms were either located by difference Fourier maps or calculated geometrically and their contributions in structural factor calculations were included. CCDC 765594 contains the supplementary crystallographic data for this paper. The data can be obtained free of charge from The Cambridge Crystallographic Data Centre via www.ccdc.cam.ac.uk/data_request/cif.

\section{Results and Discussion}

Description of Structure. Compound 1 possesses a 2-D architecture by single-crystal X-ray diffraction, in which the asymmetric unit (Figure 1) contains one crystallographic unique $\mathrm{Pb}(\mathrm{II})$ ion, one $\mathrm{L}^{\prime}$ ligand and two lattice water molecules. Crystallographic data and structural refinements are summarized in Table 1.

$\mathrm{Pb}(1)$ ion in the asymmetry unit is five-coordinated with four $\mathrm{O}$ atoms and one $\mathrm{N}$ atom from three organic ligands $\mathrm{L}$, $\mathrm{O}(1), \mathrm{O}(2), \mathrm{O}(3 \mathrm{~A}), \mathrm{O}(3 \mathrm{~B})$ and $\mathrm{N}(2 \mathrm{~A})$. The coordination geometry around the $\mathrm{Pb}(1)$ ion can be described as a $\left\{\mathrm{PbO}_{4} \mathrm{~N}\right\}$ trigonal bipyramid geometry. The $\mathrm{Pb}-\mathrm{O} / \mathrm{N}$ distances are from 2.354(3) to 2.665(4) $\AA$ in a normal bond length range of 2.2-2.8 $\AA$. The $\mathrm{O}-\mathrm{Pb}-\mathrm{O} / \mathrm{N}$ angles range from $51.36(1)^{\circ}$ to $130.45(1)^{\circ}$. Owing to stereochemical activity of the $6 \mathrm{~s}$ electrons, five-coordinate $\mathrm{Pb}$ (II) ion is inclined to form hemidirected coordination geometry which will produce distinct voids or gaps in the coordination sphere. ${ }^{12}$

When the bond length around $\mathrm{Pb}$ (II) ion extends from 2.8 $\AA$ to $3.1 \AA$, weak $\mathrm{Pb}-\mathrm{O}$ interactions can be discovered in the direction of the void or gap derived from the repulsion of the 6s electrons. $\mathrm{Pb}(1)-\mathrm{O}(1 \mathrm{w})$ distance is $2.887(4) \AA$, and $\mathrm{O} / \mathrm{N}-$

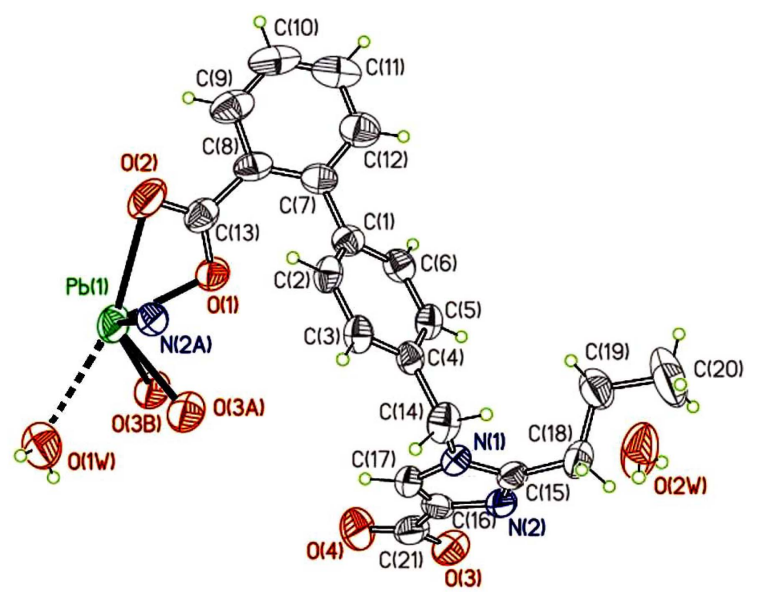

Figure 1. ORTEP view of 1 showing the atom-labeling scheme (50\% thermal ellipsoids).
$\mathrm{Pb}(1)-\mathrm{O}(1 \mathrm{w})$ bond angles are from $68.17(1)^{\circ}$ to $158.65(1)^{\circ}$. As a result, the coordination numbers of $\mathrm{Pb}(\mathrm{II})$ ion increase from five to six. At the same time the coordination geometry of $\mathrm{Pb}$ (II) ion is also changed from a distorted trigonal bipyramid to distorted octahedron. Selected bond lengths

Table 1. Crystallographic data for 1

\begin{tabular}{ll}
\hline & $\mathbf{1}$ \\
\hline Empirical formula & $\mathrm{C}_{84} \mathrm{H}_{82} \mathrm{~N}_{8} \mathrm{O}_{21} \mathrm{~Pb}_{4}$ \\
Formula weight & 592.08 \\
Temperature $(\mathrm{K})$ & $296(2)$ \\
Wavelength $(\AA)$ & 0.71073 \\
Crystal system & Monoclinic \\
Space group & $P 21 / c$ \\
Unit cell dimensions & \\
$a(\AA)$ & $13.0529(2)$ \\
$b(\AA)$ & $13.822(2)$ \\
$c(\AA)$ & $11.5345(2)$ \\
$\beta\left(^{\circ}\right)$ & $100.298(2)$ \\
Volume $\left(\AA^{3}\right)$ & $2047.5(5)$ \\
$Z$ & 1 \\
Calculated density $\left(\mathrm{g} / \mathrm{cm}^{3}\right)$ & 1.921 \\
Absorption coefficient $\left(\mathrm{mm}^{-1}\right)$ & 8.276 \\
$F(000)$ & 1138 \\
Theta range for data collection $\left(^{\circ}\right)$ & $2.16-26.00$ \\
Limiting indices & $-16 \leq h \leq 16$ \\
& $-14 \leq k \leq 17$ \\
Unique $(R($ int $))$ & $-13 \leq l \leq 14$ \\
Max. and min. transmission & $4020(0.0468)$ \\
Data / restraints / parameters & 0.191 and 0.087 \\
Goodness-of-fit on $F^{2}$ & $4020 / 0 / 272$ \\
Final $R$ indices $[I>2 \sigma(I)]$ & 0.966 \\
$R$ indices (all data) & $R_{1}=0.0327, w R_{2}=0.0641$ \\
Largest diff. peak and hole $\left(\mathrm{e} \AA^{-3}\right)$ & $R_{1}=0.0663, w R_{2}=0.0703$ \\
\hline & 0.516 and -0.860 \\
\hline &
\end{tabular}

Table 2. Selected bond lengths $[\AA]$ and angles $\left[{ }^{\circ}\right]$ for $\mathbf{1}$

\begin{tabular}{lrlr}
\hline bond lengths & & & \\
\hline $\mathrm{O}(1)-\mathrm{Pb}(1)$ & $2.354(3)$ & $\mathrm{Pb}(1)-\mathrm{O}(3)^{d}$ & $2.532(4)$ \\
$\mathrm{O}(2)-\mathrm{Pb}(1)$ & $2.665(4)$ & $\mathrm{Pb}(1)-\mathrm{N}(2)^{c}$ & $2.535(4)$ \\
$\mathrm{Pb}(1)-\mathrm{O}(3)^{c}$ & $2.393(4)$ & $\mathrm{O}(1 \mathrm{w})-\mathrm{Pb}(1)$ & $2.887(4)$ \\
\hline angles & & & \\
\hline $\mathrm{C}(15)-\mathrm{N}(2)-\mathrm{Pb}(1)^{a}$ & $140.5(4)$ & $\mathrm{O}(3)^{c}-\mathrm{Pb}(1)-\mathrm{N}(2)^{c}$ & $67.08(1)$ \\
$\mathrm{C}(16)-\mathrm{N}(2)-\mathrm{Pb}(1)^{a}$ & $112.8(3)$ & $\mathrm{O}(3)^{d}-\mathrm{Pb}(1)-\mathrm{N}(2)^{c}$ & $130.45(1)$ \\
$\mathrm{C}(13)-\mathrm{O}(1)-\mathrm{Pb}(1)$ & $101.0(3)$ & $\mathrm{O}(1)-\mathrm{Pb}(1)-\mathrm{O}(2)$ & $51.36(1)$ \\
$\mathrm{C}(13)-\mathrm{O}(2)-\mathrm{Pb}(1)$ & $87.5(3)$ & $\mathrm{O}(3)^{c}-\mathrm{Pb}(1)-\mathrm{O}(2)$ & $122.68(1)$ \\
$\mathrm{C}(21)-\mathrm{O}(3)-\mathrm{Pb}(1)^{a}$ & $124.9(4)$ & $\mathrm{O}(3)^{d}-\mathrm{Pb}(1)-\mathrm{O}(2)$ & $122.73(1)$ \\
$\mathrm{C}(21)-\mathrm{O}(3)-\mathrm{Pb}(1)^{b}$ & $118.9(4)$ & $\mathrm{N}(2)^{c}-\mathrm{Pb}(1)-\mathrm{O}(2)$ & $77.91(1)$ \\
$\mathrm{Pb}(1)^{a}-\mathrm{O}(3)-\mathrm{Pb}(1)^{b}$ & $115.85(2)$ & $\mathrm{O}(1)-\mathrm{Pb}(1)-\mathrm{O}(1 \mathrm{w})$ & $147.58(1)$ \\
$\mathrm{O}(1)-\mathrm{Pb}(1)-\mathrm{O}(3)^{c}$ & $81.33(1)$ & $\mathrm{O}(3)^{c}-\mathrm{Pb}(1)-\mathrm{O}(1 \mathrm{w})$ & $68.17(1)$ \\
$\mathrm{O}(1)-\mathrm{Pb}(1)-\mathrm{O}(3)^{d}$ & $78.88(1)$ & $\mathrm{O}(3)^{d}-\mathrm{Pb}(1)-\mathrm{O}(1 \mathrm{w})$ & $78.12(1)$ \\
$\mathrm{O}(3)^{c}-\mathrm{Pb}(1)-\mathrm{O}(3)^{d}$ & $64.15(2)$ & $\mathrm{N}(2)^{c}-\mathrm{Pb}(1)-\mathrm{O}(1 \mathrm{w})$ & $91.91(1)$ \\
$\mathrm{O}(1)-\mathrm{Pb}(1)-\mathrm{N}(2)^{c}$ & $85.90(1)$ & $\mathrm{O}(2)-\mathrm{Pb}(1)-\mathrm{O}(1 \mathrm{w})$ & $158.65(1)$ \\
\hline
\end{tabular}

Symmetry transformations used to generate equivalent atoms: ${ }^{a} \mathrm{x},-\mathrm{y}+3 /$ $2, \mathrm{z}+1 / 2 .{ }^{b}-\mathrm{x}+2, \mathrm{y}-1 / 2,-\mathrm{z}+5 / 2 .{ }^{c} \mathrm{x},-\mathrm{y}+3 / 2, \mathrm{z}-1 / 2 .{ }^{d}-\mathrm{x}+2, \mathrm{y}+1 / 2,-\mathrm{z}+5 / 2$ 
(a)

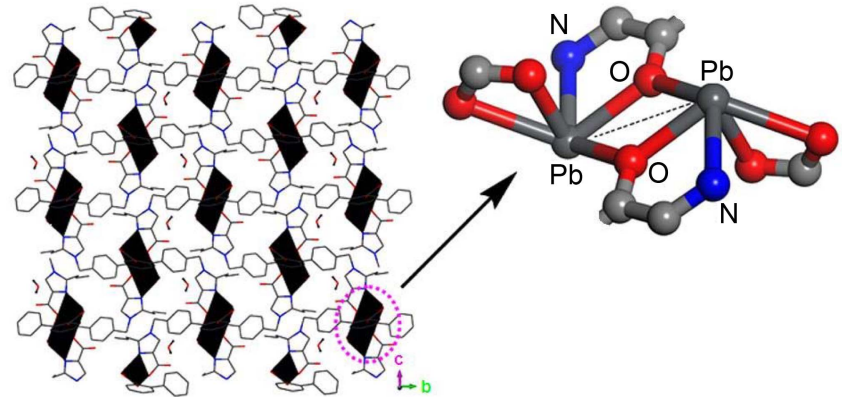

(b)

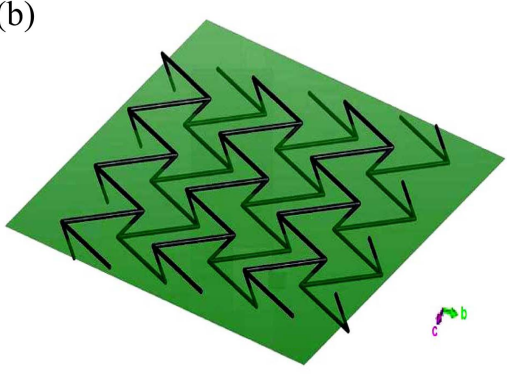

Figure 2. (a) 2-D layer built from double chains in the $b c$ plane. (b) 2-D terrace-like topological structure via lead ion as a node in the $b c$ plane.

and angles are listed in Table 2.

The ligand $L^{\prime}$ acts as a tetradentate role in $\mu_{3}: \eta^{2}: \eta^{2}: \eta^{1}$ mode in which carboxyl oxygen atoms $(\mathrm{O}(1), \mathrm{O}(2))$ from biphenyl moiety chelating with one $\mathrm{Pb}(\mathrm{II})$ ion, the carboxyl oxygen atom $(\mathrm{O}(3))$ from $N$-heterocyclic moiety in $\mu_{2}-\mathrm{O}(3)$ monodentate mode connecting to two $\mathrm{Pb}(\mathrm{II})$ ions, and nitrogen atom $(\mathrm{N}(2))$ from $N$-heterocyclic moiety bonding to one $\mathrm{Pb}$ (II) ion.

The compound 1 contains a $\left\{\mathrm{Pb}_{2} \mathrm{O}_{6} \mathrm{~N}_{2}\right\}$ (Figure 2a) core that can be described as an edge-shared dinuclear polyhedron with two $\mu_{2}-\mathrm{O}(3)$ atoms. In particular, the $\mathrm{Pb}(1)-$ $\mathrm{Pb}(1)$ contact is $4.174 \AA$ that the weaker metal-metal interactions further reinforce the dinuclear structure. Three types of four/five-membered rings, [-Pb(1)-O(3)-Pb(1)$\mathrm{O}(3)-],[-\mathrm{Pb}(1)-\mathrm{O}(1)-\mathrm{C}(13)-\mathrm{O}(2)]$ and $[-\mathrm{Pb}(1)-\mathrm{O}(3)-\mathrm{C}(21)-$ $\mathrm{C}(16)-\mathrm{N}(2)]$, are assembled in the $\left\{\mathrm{Pb}_{2} \mathrm{O}_{6} \mathrm{~N}_{2}\right\}$ core. The dinulear core $\left\{\mathrm{Pb}_{2} \mathrm{O}_{6} \mathrm{~N}_{2}\right\}$, as a basic structural unit, is joined together by the organic ligand $\mathrm{L}^{\prime}$ to form a 2-D metalorganic framework in the $b c$ plane (Figure 2a). Regarding $\mathrm{Pb}(\mathrm{II})$ ion as node, the 2-D layer actually comprises the upper-lower terrace-like double chains which further link together through $\mu_{2}-\mathrm{O}(3)$ (Figure 2b). It should be noted that the 2-D structure is the first example of this complicated ligand L', based on a Cambridge Structure Database (CSD) (Aug, 2010) search until now. ${ }^{13}$ The lattice water molecule $(\mathrm{O} 2 \mathrm{w})$ occupies the voids between the layers and is involved in hydrogen bonds. Due to the existence of the lattice water molecule, few of the voids are observed in the overall 2-D crystalline lattice. After the removal of solvent, the volume of tunnel formed by 2-D layers is $36.2 \AA^{3}$ per unit cell using PLATON based on the crystal structures, comprising $1.8 \%$ of the crystal volume. ${ }^{14}$

Except for that long $\mathrm{Pb}-\mathrm{O}(1 \mathrm{w})$ contact, there also have two types of hydrogen bonds $(\mathrm{O}-\mathrm{H} \cdots \mathrm{O}$ and $\mathrm{C}-\mathrm{H} \cdots \mathrm{O})$ in $\mathbf{1}$. These hydrogen bonds are formed between the ligand $\mathrm{L}^{\prime}$ $(\mathrm{O}(1), \mathrm{O}(2), \mathrm{O}(4), \mathrm{C}(11), \mathrm{C}(18))$ and the two water molecules $(\mathrm{O}(1 \mathrm{w}), \mathrm{O}(2 \mathrm{w}))$. The hydrogen bonds $(\mathrm{C}(11) \cdots \mathrm{O}(2 \mathrm{w})$, $\mathrm{O}(2 \mathrm{w}) \cdots \mathrm{O}(2) \mathrm{C}(18) \cdots \mathrm{O}(2 \mathrm{w})$ and $\mathrm{O}(2 \mathrm{w}) \cdots \mathrm{O}(4))$ distances and angles are 3.209(1) $\AA, 2.748(1) \AA, 3.352(2) \AA, 2.620(1)$ $\AA, 128.9^{\circ}, 129.6^{\circ}, 149.3^{\circ}$ and $160.2^{\circ}$, respectively. Accordingly, the above 2-D layers are further joined together by hydrogen bond interactions to lead to a 3-D supramolecular framework (Figure 3). The lattice water molecules play a

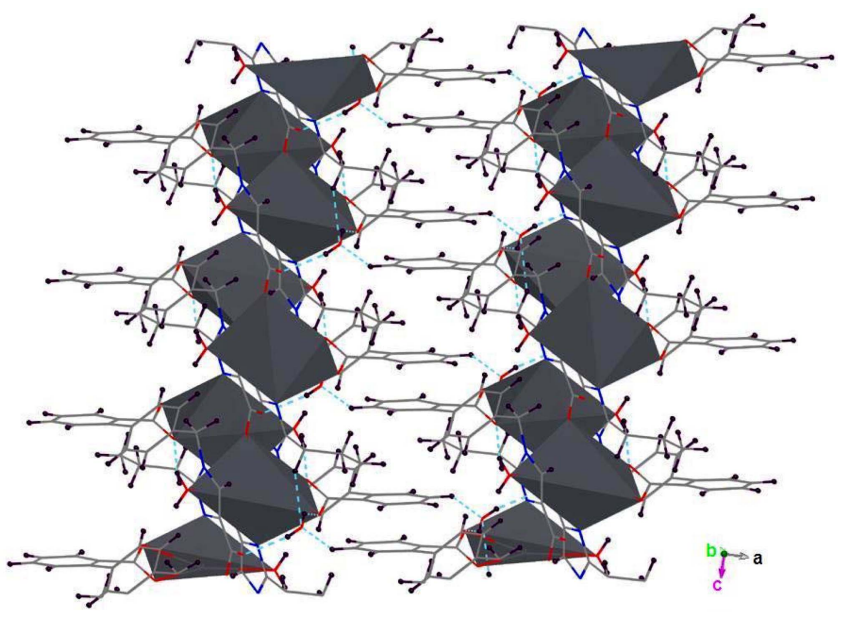

Figure 3. 3-D supramolecular network created from 2-D layers via hydrogen bond. Hydrogen bonds are drawn as blue dotted lines.

very important role in the formation of 3-D supramolecule. Hydrogen bonds and angles are given in Table 3.

XRD and TG-DTA Study. The powder XRD pattern of 1 indicates that as-synthesized product is a new material, and the pattern is entirely consistent with the simulated one from the single-crystal X-ray diffraction. Thermodiffractograms of 1 heated up to $520^{\circ} \mathrm{C}$ in air are shown in Figure 4. Results reveal no phase transformation was observed in thermodiffraction powder at a temperature below $320{ }^{\circ} \mathrm{C}$ except thermal dilatation. It means the 2-D lattice of $\mathbf{1}$ began to collapse above a temperature of $320^{\circ} \mathrm{C}$.

The combined TG-DTA analysis (see supplement figure S2) shows two major weight losses. The first mass loss of $3.74 \%$ from $60{ }^{\circ} \mathrm{C}$ to $130{ }^{\circ} \mathrm{C}$, with an endothermic peak

Table 3. Hydrogen bond lengths $[\AA]$ and angles $\left[{ }^{\circ}\right]$ for $\mathbf{1}$

\begin{tabular}{lcccc}
\hline \multicolumn{1}{c}{$\mathrm{D}-\mathrm{H} \cdots \mathrm{A}$} & $\mathrm{d}(\mathrm{D}-\mathrm{H})$ & $\mathrm{d}(\mathrm{H} \cdots \mathrm{A})$ & $\mathrm{d}(\mathrm{D} \cdots \mathrm{A})$ & $<(\mathrm{DHA})$ \\
\hline $\mathrm{O}(1 \mathrm{w})-\mathrm{H}(1 \mathrm{wA}) \cdots \mathrm{O}(1)^{a}$ & 0.85 & 2.01 & $2.771(5)$ & 148.5 \\
$\mathrm{O}(2 \mathrm{w})-\mathrm{H}(2 \mathrm{w} 1) \cdots \mathrm{O}(4)^{b}$ & 0.72 & 1.93 & $2.620(1)$ & 160.2 \\
$\mathrm{O}(2 \mathrm{w})-\mathrm{H}(2 \mathrm{w} 2) \cdots \mathrm{O}(2)^{c}$ & 0.71 & 2.24 & $2.748(1)$ & 129.6 \\
$\mathrm{C}(11)-\mathrm{H}(11) \cdots \mathrm{O}(2 \mathrm{w})^{d}$ & 0.93 & 2.54 & $3.209(1)$ & 128.9 \\
$\mathrm{C}(18)-\mathrm{H}(18 \mathrm{~B}) \cdots \mathrm{O}(2 \mathrm{w})$ & 0.93 & 2.48 & $3.352(2)$ & 149.3
\end{tabular}

Symmetry transformations used to generate equivalent atoms: ${ }^{a}-\mathrm{x}+2$, $-\mathrm{y}+2,-\mathrm{z}+2 .^{b}-\mathrm{x}+2,-\mathrm{y}+1,-\mathrm{z}+2 .{ }^{c} \mathrm{x}, \mathrm{y}-1, \mathrm{z} .{ }^{d}-\mathrm{x}+1, \mathrm{y}-1 / 2,-\mathrm{z}+1 / 2$ 


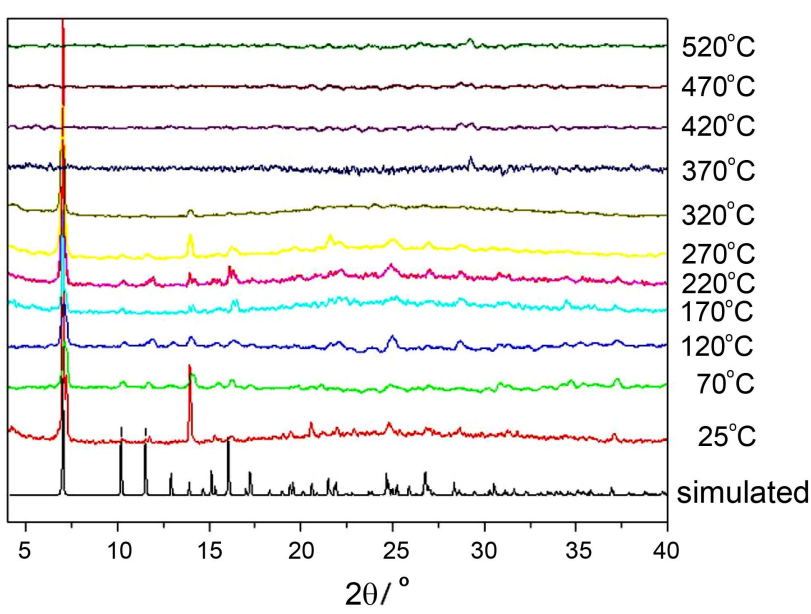

Figure 4. The powder XRD patterns of $\mathbf{1}$.

centered at $80{ }^{\circ} \mathrm{C}$, corresponds to the loss of two lattice water molecules (calc. 3.80\%). The broad range to lose the lattice water molecules is much more likely to attribute to those complicated hydrogen bonds. ${ }^{15}$ The second mass loss of about $58.16 \%$ (calc. $58.50 \%$ ), in the range of $320-500{ }^{\circ} \mathrm{C}$, can be assigned to the pyrolysis of the organic ligand. Three exothermic peaks, centered at $328{ }^{\circ} \mathrm{C}, 409{ }^{\circ} \mathrm{C}$ and $455^{\circ} \mathrm{C}$, indicate structural changes. These changes are reflected in diffraction patterns at $370,420,470$ and $520{ }^{\circ} \mathrm{C}$. The final thermal decomposition residue at $800{ }^{\circ} \mathrm{C}$ is $\mathrm{PbO}$, which possesses a mass of $38.1 \%$ (calc. $37.7 \%$ ).

Photoluminescent Property. According to work reported previously, coordination polymers containing $\mathrm{Pb}(\mathrm{II})$ ions can exhibit photoluminescent properties. ${ }^{4-6}$ Here, we investigated the solid-state photoluminescent property of $\mathbf{1}$ heated at different temperatures (Figure 5). The free raw material $\mathrm{H}_{3} \mathrm{~L}$ shows a fluorescent emission in the visible region at $482 \mathrm{~nm}\left(\lambda_{\text {excitation }}=390 \mathrm{~nm}\right)$, whereas the compound 1 shows four emission bands at $458 \mathrm{~nm}, 555 \mathrm{~nm}, 600 \mathrm{~nm}$ and $719 \mathrm{~nm}$ $\left(\lambda_{\text {excitation }}=390 \mathrm{~nm}\right)$, respectively. Three small emission bands at $545 \mathrm{~nm}, 585 \mathrm{~nm}$ and $703 \mathrm{~nm}\left(\lambda_{\text {excitation }}=390 \mathrm{~nm}\right)$ are still observed even though the samples were heat-treated at above $320^{\circ} \mathrm{C}$. This suggests that an emission maximum at

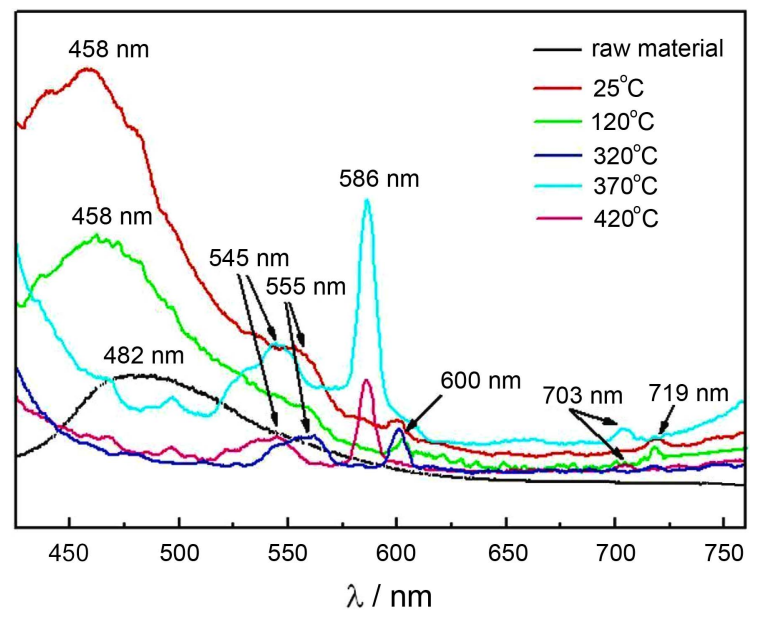

Figure 5. Solid-state emission spectra of $\mathbf{1}$.
$458 \mathrm{~nm}$ may be assigned to $\pi^{*}-n$ and $\pi^{*}-\pi$ electronic transitions within the aromatic systems of the ligand L'. The blue shift about $24 \mathrm{~nm}$, compared to that of the free $\mathrm{H}_{3} \mathrm{~L}$, may be due to the coordination or an excited state of a metalperturbing intraligand. After the title compound was heat treated at the temperature of above $320{ }^{\circ} \mathrm{C}$, X-ray powder diffraction show that the originally crystalline material changes take place. So the bands $555 \mathrm{~nm}, 600 \mathrm{~nm}$ and 719 $\mathrm{nm}$ may be assigned to phosphorescent emission. Owing to the presence of a heavy metal lead(II) ion, the radiationless deactivations of the triplet state can facilitate the intersystem crossing successfully. These results indicate the $\mathrm{Pb}$ (II) ion might give rise to effect on the photoluminescent properties through structural modifications by change organic ligand.

\section{Conclusions}

In summary, we have successfully synthesized a novel 2-D $\mathrm{Pb}$ (II)-L' compound under hydrothermal condition by decarboxylation. The compound 1 displays 2-D layer architecture with three types of four/five-membered rings around $\mathrm{Pb}$ (II) ion. The $\mathrm{Pb}$ (II) ion is five-coordinated with three adjacent organic ligand $\mathrm{L}^{\prime}$ and an upper-lower double layer topological structure has been further built from $\left\{\mathrm{Pb}_{2} \mathrm{O}_{6} \mathrm{~N}_{2}\right\}$ core. In addition, hydrogen bonds have also led to the production of 3-D supramolecular structure. The solid-state fluorescence measurement of $\mathbf{1}$ reveals a fluorescent emission band at $458 \mathrm{~nm}$ under excitation of $390 \mathrm{~nm}$, likely caused by the ligand L' and lone electron pair of lead (II) ion.

Acknowledgments. The authors are grateful to the financial support from The National Natural Science Foundation of China, Open Fund of Jiangsu Key Laboratory for Chemistry of Low-dimensional Materials, Huai'an Scientific and technological support industrial projects and the Natural Science Foundation of the Higher Education Institutions of Jiangsu Province, China, (Projects Nos. 20671038, JSKC09068, HAG09054-12 and 10KJD150001).

Supporting Information Available. Supporting Information are available on request from the correspondence author (fax: +86 51783525100 email: kuirongma@163.com)

\section{References}

1. Fan, S. R.; Zhu, L. G. Inorg. Chem. 2007, 46, 6785.

2. Ma, K. R.; Zhang, D. J.; Zhu, Y. L. Aust. J. Chem. 2010, 63, 452.

3. Yang, J.; Ma, J. F.; Liu, Y. Y.; Ma, J. C.; Batten, S. R. Inorg. Chem. 2007, 46, 6542.

4. Chen, S. C.; Zhang, Z. H.; Chen, Q.; Gao, H. B.; Liu, Q.; He, M.; Du, Y. M. Inorg. Chem. Commu. 2009, 12, 835.

5. Ma, K. R.; Xu, J. N.; Wang, L.; Shi, J.; Wang, Y.; Ha, J.; Ning, D. K.; Fan, Y.; Song, T. Y. Chem. J. Chinese U. 2007, 28, 1434.

6. Zhang, K. L.; Pan, Z. C.; Chang, Y.; Liu, W. L.; Ng, S. W. Mater. Lett. 2009, 63, 2136.

7. Zhao, Y. H.; Xu, H. B.; Shao, K. Z.; Xing, Y.; Su, Z. M.; Ma, J. F. Cryst. Growth Des. 2007, 7, 513.

8. Zhu, X. D.; Li, X. J.; Liu, Q. Y.; Lv, J.; Guo, Z. G.; He, J. R.; Li, Y. F.; Cao, R. J. Solid State Chem. 2007, 180, 2386. 
9. Zhang, K. L.; Zhou, F.; Wub, R.; Yang, B.; Ng, S. W. Inorg. Chim. Acta. 2009, 362, 4255.

10. Zhang, K. L.; Liang, W.; Chang, Y.; Yuan, L. M.; Ng, S. W. Polyhedron 2009, 28, 647.

11. Collman, J. P.; Boulatov, R.; Sunderland, C. J.; Zhong, M. J. Fluorine Chem. 2000, 106, 189.
12. Shimoni-Livny, L.; Glusker, J. P.; Bock, C. W. Inorg. Chem. 1998 , $37,1853$.

13. Allen, F. H. Acta Crystallogr. Sect. B: Struct. Sci. 2002, 58, 380.

14. Spek, A. L. J. Appl. Cryst. 2003, 36, 7.

15. Kong, D. Y.; Clearfield, A. Cryst. Growth Des. 2005, 5, 1263. 